Cite this: Nanoscale, 2014, 6, 6046

Received 30th January 2014 Accepted 14th April 2014

DOI: $10.1039 / c 4 n r 00595 c$

www.rsc.org/nanoscale

\section{Diagnostic nanoparticle targeting of the EGF-receptor in complex biological conditions using single-domain antibodies $\uparrow$}

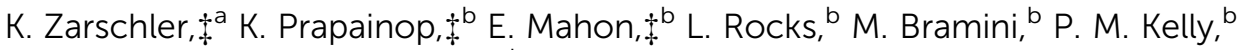 \\ H. Stephan*a and K. A. Dawson*b
}

For effective localization of functionalized nanoparticles at diseased tissues such as solid tumours or metastases through biorecognition, appropriate targeting vectors directed against selected tumour biomarkers are a key prerequisite. The diversity of such vector molecules ranges from proteins, including antibodies and fragments thereof, through aptamers and glycans to short peptides and small molecules. Here, we analyse the specific nanoparticle targeting capabilities of two previously suggested peptides (D4 and GE11) and a small camelid single-domain antibody (sdAb), representing potential recognition agents for the epidermal growth factor receptor (EGFR). We investigate specificity by way of receptor RNA silencing techniques and look at increasing complexity in vitro by introducing increasing concentrations of human or bovine serum. Peptides D4 and GE11 proved problematic to employ and conjugation resulted in non-receptor specific uptake into cells. Our results show that sdAbfunctionalized particles can effectively target the EGFR, even in more complex bovine and human serum conditions where targeting specificity is largely conserved for increasing serum concentration. In human serum however, an inhibition of overall nanoparticle uptake is observed with increasing protein concentration. For highly affine targeting ligands such as sdAbs, targeting a receptor such as EGFR with low serum competitor abundance, receptor recognition function can still be partially realised in complex conditions. Here, we stress the value of evaluating the targeting efficiency of nanoparticle constructs in realistic biological milieu, prior to more extensive in vivo studies.

\section{Introduction}

Precise delivery of therapeutics, diagnostics or theranostics to specific tissues represents one of the major challenges in cancer imaging and therapy. Through intensive research in the area of nanomedicine, significant progress has been made in order to address the issue of targeted drug delivery to tumours for cancer treatment. ${ }^{1-3}$ It is widely proposed that accumulation of nanoparticles at the tumour site can be achieved by passive and active targeting, or frequently by a combination of both. ${ }^{4-10}$ The former strategy selectively utilizes the unique pathophysiology of tumours, such as the enhanced penetration and retention effect as well as their characteristic tumour microenvironment. ${ }^{11-17}$ For active targeting, biorecognition molecules

anstitute of Radiopharmaceutical Cancer Research, Helmholtz-Zentrum Dresden-Rossendorf, Bautzner Landstraße 400, D-01328 Dresden, Germany. E-mail: h.stephan@hzdr.de

${ }^{b}$ Centre For BioNano Interactions (CBNI), School of Chemistry and Chemical Biology, University College Dublin, Belfield, Dublin 4, Ireland. E-mail: kenneth.a.dawson@ cbni.ucd.ie

$\dagger$ Electronic supplementary information (ESI) available. See DOI: 10.1039/c4nr00595c

\$ These authors contributed equally to this work. (ligands) directed against selected tumour biomarkers are grafted to the nanoparticle surface to increase and specify their delivery through specific ligand-biomarker interactions. The nature of these ligands investigated in clinical and preclinical studies is very diverse ranging from proteins, including antibodies and fragments thereof, through aptamers and glycans to short peptides and small non-proteinaceous molecules. ${ }^{\mathbf{1 8 - 2 0}}$ However, regarding clinical translation, while the limited success of current nanoparticle formulations in achieving highly effective biorecognition can be attributed to various reasons, it is currently incompletely understood. ${ }^{21,22}$ The fact that actively targeted nanoparticles often fail to show benefit at the (pre-)clinical stage can originate in difficulties these objects encounter in finding their target cells in vivo. ${ }^{23}$ Dynamic interactions of functionalized nanoparticles with components of complex biological fluids have been identified as only one reason for the dampening, and in some cases even disappearance, of targeting ability and specificity. ${ }^{24-26}$ Immediately upon exposure of nanoparticle-based agents to a biological environment, macromolecules, such as proteins and lipids, tend to adsorb to their surface and a biomolecular "corona" is formed..$^{27,28}$ These non-specific binding processes can have a major influence on cellular nanoparticle uptake ${ }^{29,30}$ as well as on 
the biorecognition and interaction of surface-grafted targeting moieties with their corresponding receptors. ${ }^{25,26}$ We stress that this loss of specificity in targeting capacity need not necessarily diminish the overall uptake into cells. This would lead to an inability to discriminate between non-cancerous cells and tumour cells based on receptor profiles. This issue is significant, since avoiding deposition in non-targeted tissues and organs is particularly critical for radiolabelled nanoparticlebased diagnostic agents and other potentially toxic drugs. Different ligands may be affected in different ways by the biological environment, ranging from complete loss of specificity to partial loss. Here we stress the value of preliminary targeting studies in realistic milieu, prior to more extended (for example, in vivo) studies.

We begin by comparing the targeting capabilities of two peptides and a small single-domain antibody exemplified by the epidermal growth factor receptor (EGFR). This $170 \mathrm{kDa}$ transmembrane glycoprotein is involved in critical cellular processes such as proliferation, differentiation and apoptosis. ${ }^{31,32}$ In a variety of solid tumours, including head and neck, breast, nonsmall-cell lung and glioblastomas, EGFR is constitutively activated as a result of receptor overexpression, mutation or deregulation..$^{33-35}$ As other members of the ErbB-family, EGFR represents a validated target for anti-cancer therapy. ${ }^{36-39}$ The current successful approaches include inhibitory antibodies such as Cetuximab and Panitumumab, which prevent EGFR ligands from interacting and activating the receptor as well as receptor-ligand internalisation. ${ }^{40}$ However, the large size and long half-life of full monoclonal antibodies represent serious disadvantages for the application of monoclonal antibodies in imaging and therapy. They are taken up by various normal tissues, especially accumulating in the liver, and are cleared relatively slowly from the blood stream. Additionally, the diffusion through and penetration into solid tumours is rather poor. ${ }^{41}$ The optimal probe for multimodal imaging is characterised by fast tissue penetration and rapid circulation clearance as well as high tumour and low liver uptake. Ultrasmall nanoparticles have been proposed to comply with these requirements and thus represent promising next-generation tumour-targeting nanotracers. To maintain their small size, targeting moieties with low spatial dimensions such as peptides, aptamers and antibody fragments are needed.
In the present investigation, the preparation of EGFR-targeted fluorescent silica nanoparticles by conjugation of specific peptides or single-domain antibodies, respectively, is reported. The latter targeting moieties are antagonistic camelid-derived variable domains binding the extracellular domain of the receptor. $^{42,43}$ Both peptide ligands, GE11 (GYHWYGYTPQNVI) $^{\mathbf{4 4 - 4 7}}$ and D4 (LARLLT), ${ }^{\mathbf{4 7} 48}$ have been recently reported to bind EGFR-positive cells in vitro and in vivo, GE11 interacts with the EGF binding pocket whereas D4 binds to a distant epitope of the extracellular domain.

\section{Results and discussion}

\section{Characterization of synthesised nanoparticles}

Fluorescently labelled silica nanoparticles $\left(\mathrm{SiO}_{2}\right)$ were successfully functionalized with EGFR-specific peptides D4 $\left(\mathrm{SiO}_{2}-\mathrm{D} 4\right)$ and GE11 ( $\left.\mathrm{SiO}_{2}-\mathrm{GE} 11\right)$ as well as with the single-domain antibody $7 \mathrm{C} 12\left(\mathrm{SiO}_{2}-\mathrm{SdAb}\right)$. The initial amine functionalized nanoparticles consistently displayed a surface density of $6 \mathrm{NH}_{2}$ per $\mathrm{nm}^{2}$, measured by ninhydrin assay, while bifunctional PEG linkers attached with a density of around 1 SMPEG per $\mathrm{nm}^{2}$, according to thermogravimetric analysis. Bioconjugation was then confirmed, following extensive centrifugal cleaning, by micro BCA protein assay against PEG controls. Characterization of nanoparticle conjugates by dynamic light scattering (DLS) and differential centrifugal sedimentation (DCS) showed a shift in apparent particle size after functionalisation with targeting moieties (Table 1 and Fig. 1). The increase in the hydrodynamic diameter upon peptide/protein conjugation without substantial alteration in the polydispersity indices indicated the formation of relatively monodisperse nanoparticle conjugates.

\section{Binding and uptake of fluorescent nanoparticles}

In order to investigate EGFR-specific targeting of functionalized nanoparticles, we analysed binding and uptake in the epithelial cell line FaDu originating from a squamous cell carcinoma of the hypopharynx. ${ }^{50}$ These human head and neck tumour cells express approximately $7 \times 10^{5}$ EGFR molecules per cell, which represents a moderate expression level. ${ }^{51,52}$ Moreover, RNA interference (RNAi) was used to knockdown the expression of the receptor in these cells to determine the effect of the targeting moieties on nanoparticle uptake. It has been shown

Table 1 Characteristics of nanoparticle conjugates and corresponding targeting ligands

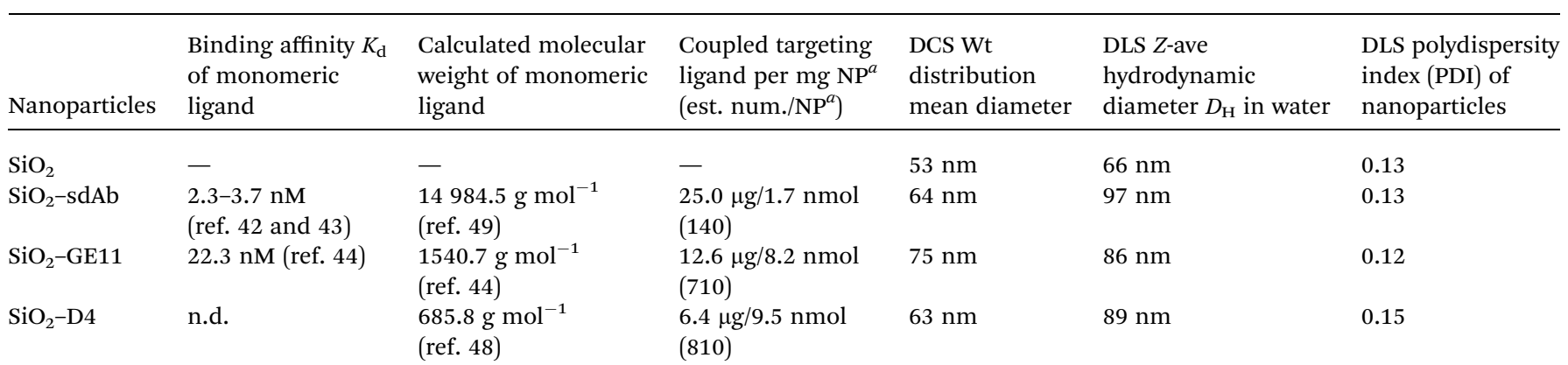

${ }^{a}$ Assuming spherical $53 \mathrm{~nm}$ core size. 

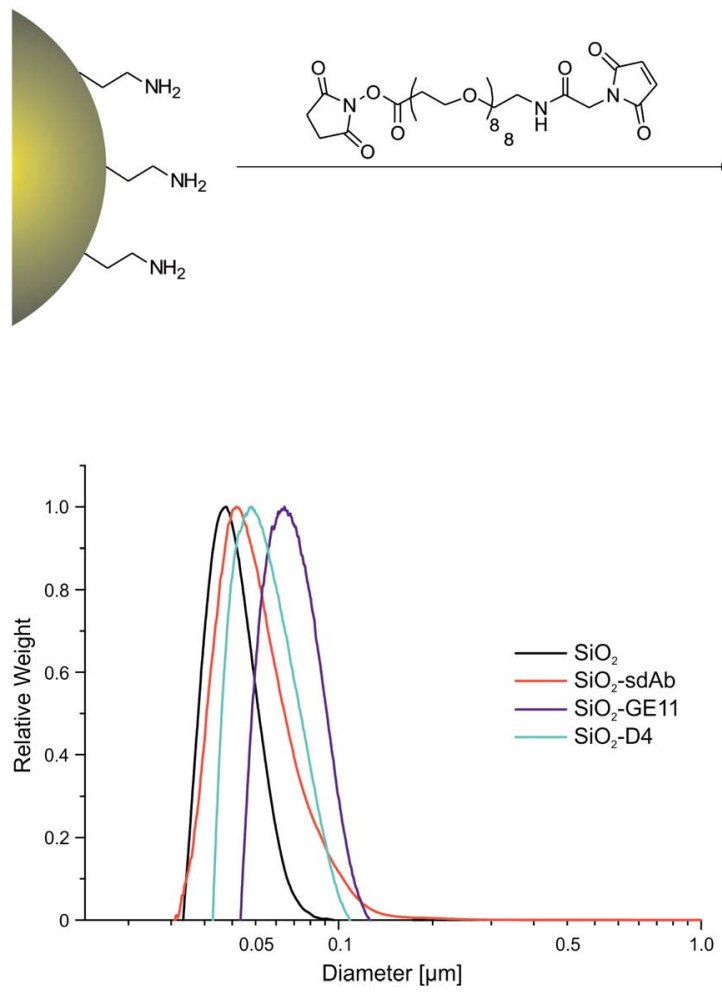
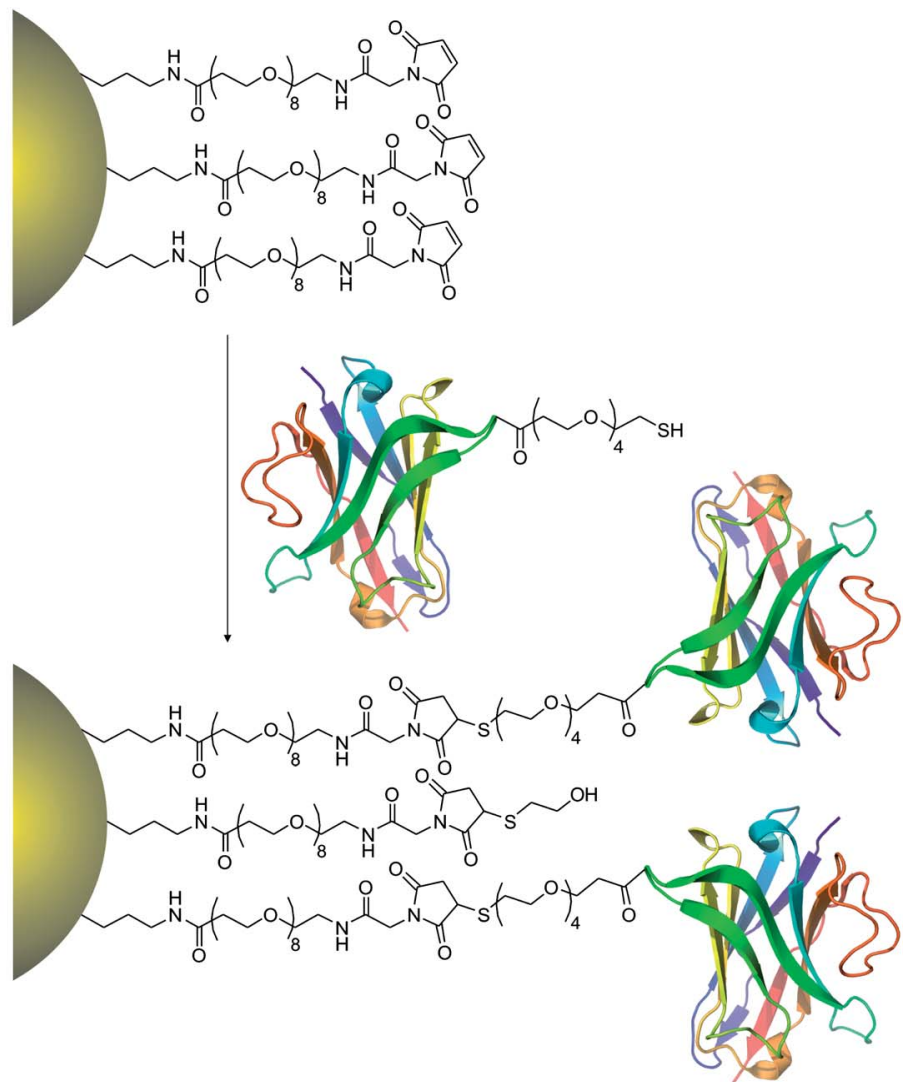

Fig. 1 Surface functionalisation of fluorescently labelled silica nanoparticles $\left(\mathrm{SiO}_{2}\right)$. Fluorescently labelled $\mathrm{SiO}_{2}(50 \mathrm{~nm})$ were functionalized with EGFR-affine peptides (D4, GE11) or single-domain antibodies (sdAbs). The insert shows nanoparticle characterisation by differential centrifugal sedimentation (DCS). Black: silica cores, turquoise: $\mathrm{SiO}_{2}-\mathrm{GE} 11$, purple: $\mathrm{SiO}_{2}-\mathrm{D} 4$, red: $\mathrm{SiO}_{2}-\mathrm{sdAbs}$.

recently that the absolute uptake level does not simply give information on the specificity of the targeting moiety on nanoparticles to relevant receptors; however, the difference of particle uptake in silenced and non-silenced cells can be used to indicate the relative contribution made by the specific pathway. ${ }^{26}$ Two validated small interfering RNA (siRNA) duplexes referred to as SiEGFR-1 and SiEGFR-2, both targeting different regions of the target mRNA, were separately introduced into FaDu cells. The efficiency of the gene silencing was determined by measuring the reduction of EGFR-encoding mRNA using quantitative real time PCR (Fig. S1A $\dagger$ ). Furthermore, the uptake of fluorescently labelled EGF by silenced and non-silenced FaDu cells was analysed by flow cytometry (Fig. S1B $\dagger$ ) and confocal microscopy (Fig. S1C and $\mathrm{D}_{\dagger}^{\dagger}$ ). Successful knockdown of EGFR was observed using either of the siRNA duplexes as seen by the reduction of about $90 \%$ of mRNA after $48 \mathrm{~h}$ post-transfection (Fig. S1A $\dagger$ ). In addition, reduction of cell surface located EGFR was confirmed by a decrease in Alexa Fluor ${ }^{\circledR}$ 488-EGF binding by siEGFR-2 silenced FaDu cells from both flow cytometry and confocal microscopy.

Cell binding and uptake of peptide functionalized nanoparticles $\mathrm{SiO}_{2}-\mathrm{D} 4$ and $\mathrm{SiO}_{2}$-GE11 were determined by flow cytometry in EGFR-positive FaDu cells as well as in EGFRnegative MDA-MB-435S cells originally isolated from a ductal adenocarcinoma of the breast (Fig. 2)..$^{53}$
For both types of peptide functionalized nanoparticles, a high cellular uptake into EGFR-positive and EGFR-negative cells was observed. This, together with the fact that uptake rates are

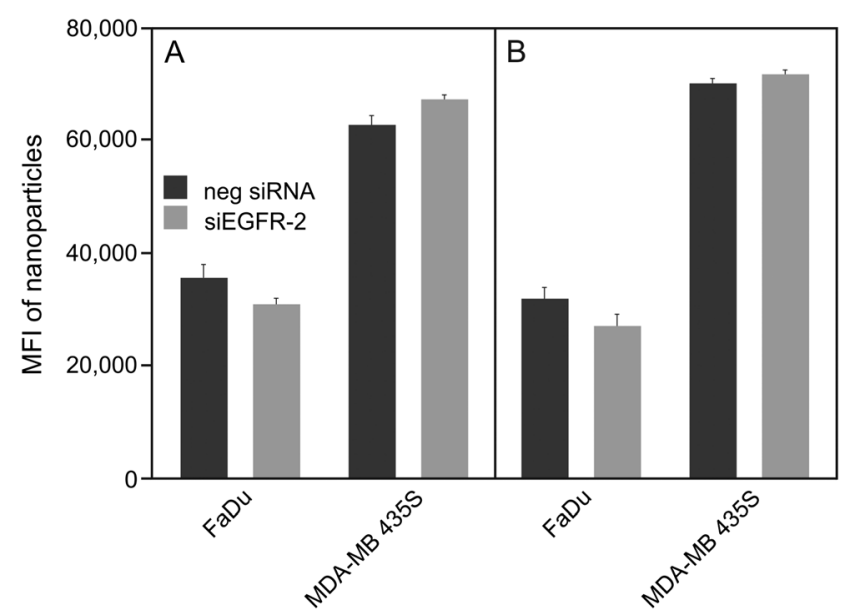

Fig. 2 Uptake of peptide-functionalized nanoparticles by different cancer cell lines. EGFR-positive FaDu and EGFR-negative MDA-MB $435 \mathrm{~S}$ cells were silenced for $48 \mathrm{~h}$ with negative silencer control (neg siRNA) and siRNA for EGFR (siEGFR-2) prior to exposure to $100 \mu \mathrm{g} \mathrm{mL}^{-1} \mathrm{SiO}_{2}-\mathrm{D} 4$ (A) or $\mathrm{SiO}_{2}-\mathrm{GE11}$ (B). Median cell fluorescence intensity was measured by flow cytometry, showing that the uptake is not reduced in cells silenced for EGFR. 
almost equal between silenced and non-silenced FaDu cells provides evidence that $\mathrm{SiO}_{2}-\mathrm{D} 4$ as well as $\mathrm{SiO}_{2}-\mathrm{GE} 11$ were largely not taken up by EGFR-specific pathway. Interestingly, it has been shown previously that GE11 conjugated to cationic polyethylenimine, fluorescein isothiocyanate or polar liposomes showed uptake into EGFR-expressing cells, but no internalization into EGFR-negative cells. ${ }^{\mathbf{4 4 - 4 6}}$ However, Ongarora et al. observed only poor uptake of phthalocyanine-GE11 conjugates, whereas phthalocyanine-D4 derivatives accumulated in different tumour cell lines. ${ }^{47}$ These partially contradictory outcomes illustrate that the chemical nature of the conjugates and their characteristics such as charge and polarity may have a substantial influence on their specific tumour targeting abilities. Since both peptides, D4 as well as GE11, appeared to be incompatible with the herein utilised nanoparticle platform, single-domain antibodies (sdAbs) representing alternative EGFR-specific targeting moieties were attached to the surface of silica nanoparticles $\left(\mathrm{SiO}_{2}-\mathrm{SdAb}\right)$. Exposure of silenced and non-silenced FaDu cells to sdAb-conjugated nanoparticles reveals substantial disparities in the level of uptake between both cell populations (Fig. 3).

Knockdown of EGFR expression leads to a reduction of uptake of about $65 \%$ suggesting a predominant receptor dependent binding and internalisation of $\mathrm{SiO}_{2}-\mathrm{sdAb}$ (Fig. 3A). Moreover, confocal imaging of EGFR-positive FaDu cells shows co-localization of sdAb-conjugated nanoparticles with EGFR after $30 \mathrm{~min}$ exposure and internalisation as well as accumulation in the lysosomes after $6 \mathrm{~h}$. Almost no interaction of $\mathrm{SiO}_{2}-$ sdAb was observed by confocal microscopy of silenced FaDu cells even after $6 \mathrm{~h}$ of exposure (Fig. 3B). Similar results were obtained for the epidermoid carcinoma cell line A431 (Fig. S2 $\dagger$ ), which is characterised by strong overexpression of EGFR with 1$3 \times 10^{6}$ receptors per cell. ${ }^{5,55}$ Although these results prove EGFR-specific binding and uptake of sdAb-functionalized silica nanoparticles in buffer or serum-free medium, efficient targeting in more realistic biological environments is an essential prerequisite for later in vivo application. It has been shown recently, that the transfer of nanoparticles into a complex biological environment, e.g. serum, leads to the formation of a dynamic protein corona on the surface of nanoparticles. ${ }^{56,57}$ These corona components may block the interactions of targeting moieties conjugated to the nanoparticle surface with their putative target and cause a loss of targeting specificity. ${ }^{25,26,58}$ In order to verify $\mathrm{SiO}_{2}-\mathrm{SdAb}$ targeting to EGFR of FaDu cells in a biological milieu, we investigated their cellular binding and uptake in presence of different concentration of both human serum and foetal calf serum (Fig. 4). Increasing concentrations of human serum interfere with overall $\mathrm{SiO}_{2}-$ sdAb uptake (Fig. 4A), however, the fraction of uptake via EGFR does not decrease substantially (Fig. 4B). In the presence of foetal calf serum, FaDu cells internalise sdAb-functionalized silica nanoparticles to a greater extent compared to human serum. For both sera, the reduction of overall uptake levels can be related the formation of a protein corona. ${ }^{29}$ To further investigate this, nanoparticles were exposed to $50 \mathrm{mg} \mathrm{mL}^{-1}$ of human serum and the associated biomolecular corona was isolated as described previously. ${ }^{59}$ As shown in Fig. 5, grafting of a PEG linker interlayer and sdAbs on the surface of nanoparticles obviously reduces the non-specific adsorption of serum proteins. Such a functionalisation strategy has been shown recently to largely but not completely suppress serum protein adsorption. ${ }^{26}$

The observed differences in cellular internalisation between human and foetal calf serum in spite of similar protein concentrations might be caused by characteristic components of the particular serum. These include soluble, serum-resident forms of EGFR, ${ }^{60}$ which bind and block the antigen binding regions of the sdAbs conjugated to silica nanoparticles. Such
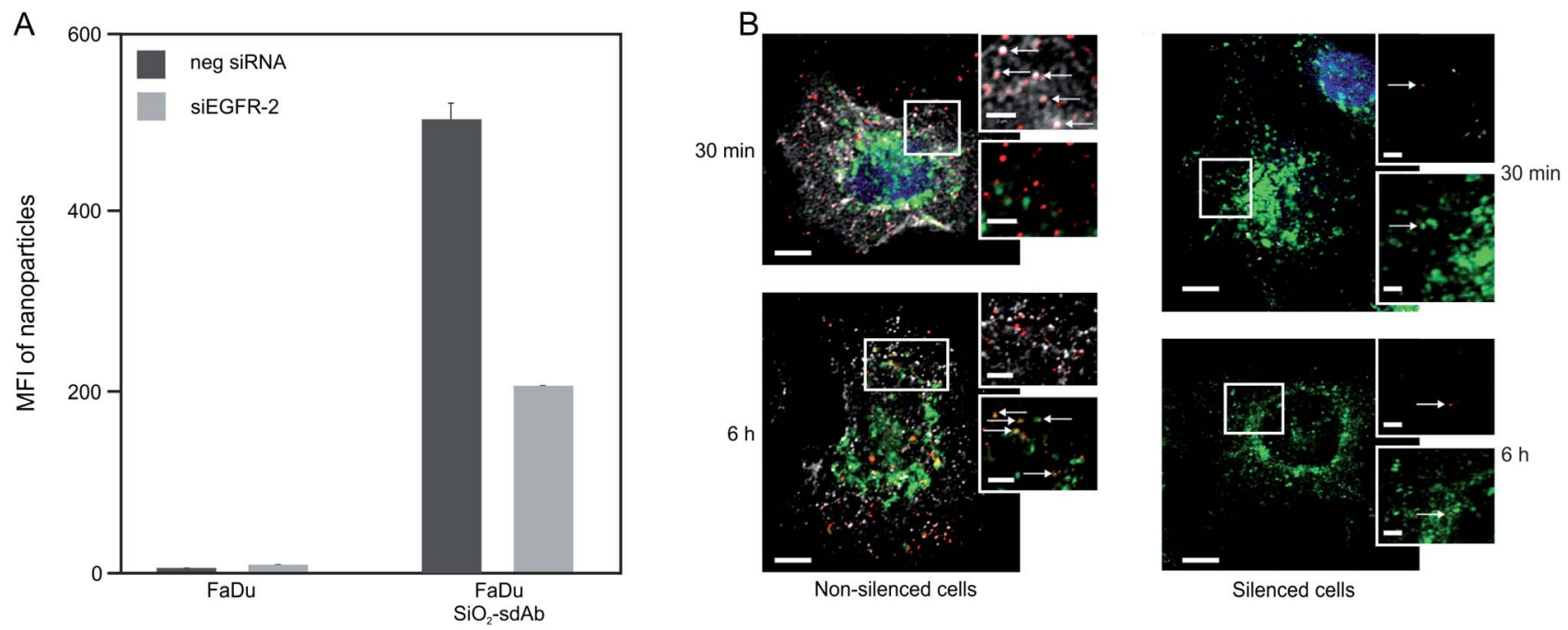

Fig. 3 Uptake of sdAb-functionalized nanoparticles by FaDu cells. Median cell fluorescence intensity determined by flow cytometry of FaDu cells exposed to $10 \mu \mathrm{g} \mathrm{mL}^{-1}$ of $\mathrm{SiO}_{2}-\mathrm{sdAb}$ showing that the uptake is strongly affected by EGFR knockdown (A). Confocal microscopy images of non-silenced and silenced FaDu cells exposed to $\mathrm{SiO}_{2}-\mathrm{sdAb}$ nanoparticles for 30 min and $6 \mathrm{~h}$ in serum free DMEM (B). Nanoparticles in red, LAMP-1 in green and EGFR in white. Scale bars of $10 \mu \mathrm{m}$ for the main images and $2 \mu \mathrm{m}$ for the zoomed images. 

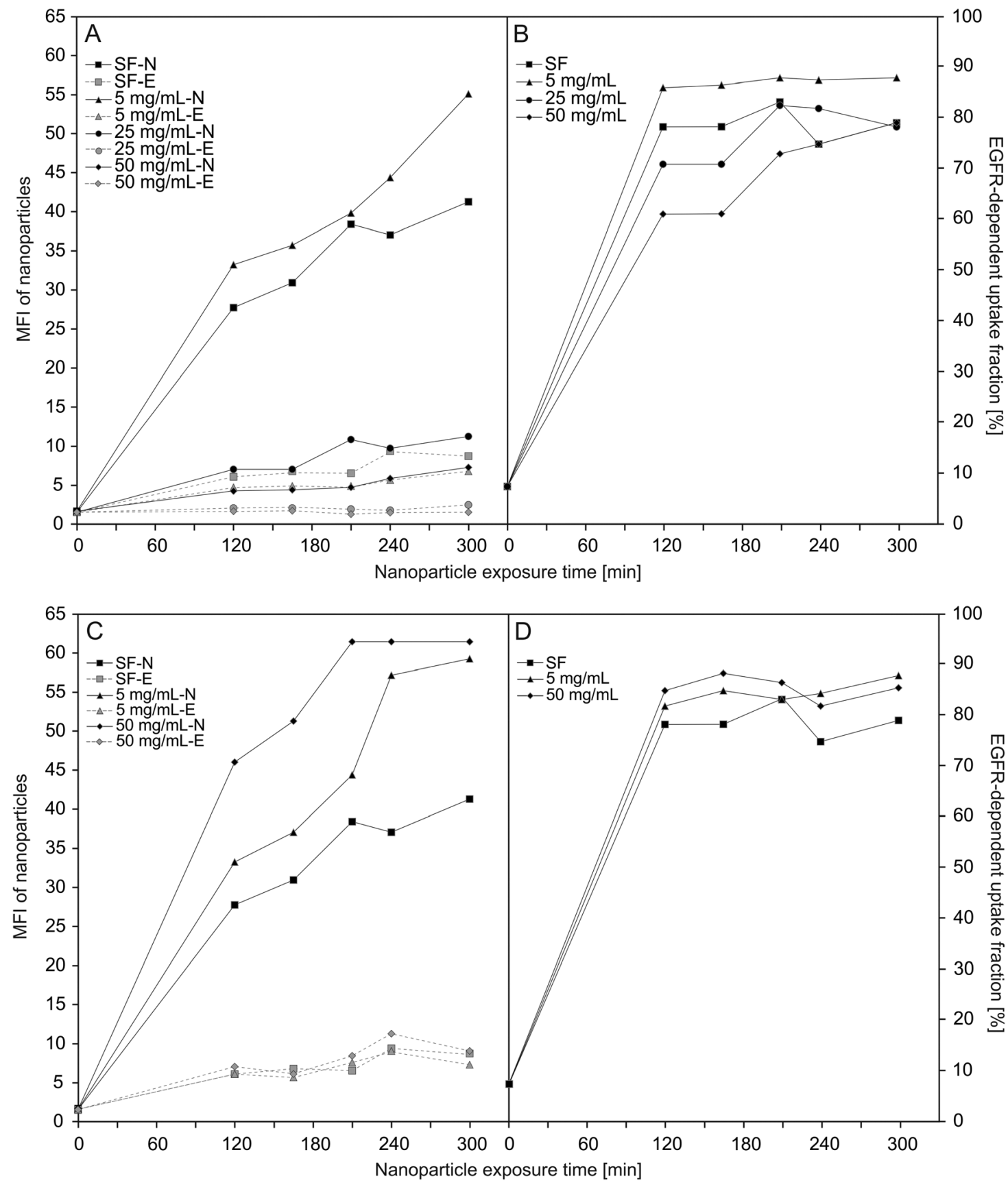

Fig. 4 Uptake of $\mathrm{SiO}_{2}-\mathrm{sdAb}$ in different concentration of human (A/B) and foetal calf (C/D) serum. Median cell fluorescence intensity measured by flow cytometry of silenced (-E) and non-silenced (-N) FaDu cells exposed to $10 \mu \mathrm{g} \mathrm{mL} \mathrm{L}^{-1}$ of $\mathrm{SiO}_{2}-\mathrm{sdAb}$ in serum-free medium (SF) and medium supplemented with human (A) or foetal calf $(C)$ serum, respectively, showing that the uptake is strongly dependent on the present concentration of serum. The EGFR-dependent fractions were calculated using the difference in fluorescence between non-silenced (neg siRNA) and silenced (siEGFR-2) cells divided by the fluorescence of non-silenced cells from the uptake curves in (A) or (C), e.g. ((non-silenced silenced)/non-silenced). This allows quantifying that, in spite of increasing serum concentrations, the fraction of uptake depending on EGFR remains high $(B / D)$.

EGFR analogs lack the cytoplasmic and transmembrane domains of the receptor and originate either from alternative splicing of primary mRNAs or from proteolytic cleavage of fulllength EGFR isoforms. ${ }^{61}$ Also human EGF representing an endogenous competitor for sdAb-mediated EGFR binding of nanoparticle conjugates may contribute to the identified effect, that $\mathrm{FaDu}$ cells internalise $\mathrm{SiO}_{2}-\mathrm{sdAb}$ to a lesser extent in human compared to foetal calf serum.

\section{Characterisation of radiolabelled nanoparticles}

The sdAb-functionalized silica nanoparticles were further modified with 1,4,7-triazacyclononane-triacetic acid (NOTA) in 


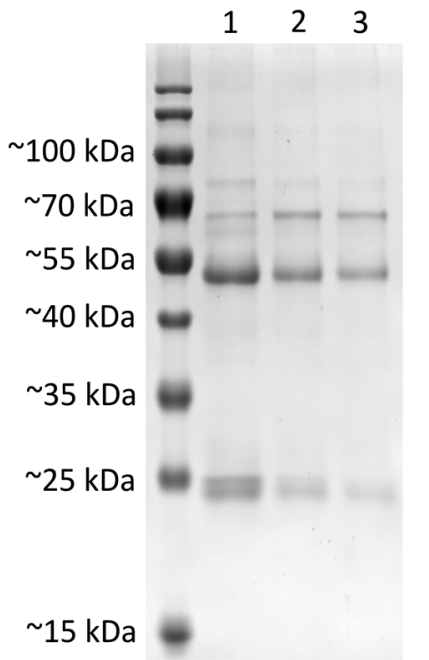

Fig. 5 SDS-PAGE analysis of protein corona composition on $\mathrm{SiO}_{2}$ nanoparticles upon incubation in $50 \mathrm{mg} \mathrm{mL}^{-1}$ of human serum. Nanoparticle surface associated proteins were isolated after incubation of $\mathrm{SiO}_{2}$ (lane 1), $\mathrm{SiO}_{2}-\mathrm{sdAb}$ (lane 2) or $\mathrm{SiO}_{2}-\mathrm{sdAb}-\mathrm{NOTA}$ (lane 3) with $50 \mathrm{mg} \mathrm{mL}^{-1}$ of "off the clot" human serum. Attachment of sdAbs on the surface of nanoparticles obviously reduces the unspecific adsorption of serum proteins, whereas further functionalisation with the copper-64 chelator 1,4,7-triazacyclononane-triacetic acid (NOTA) shows minimal influence on corona composition.

order to achieve the attachment of $\mathrm{a}^{64} \mathrm{Cu}$ radiolabel for positron emission tomographic (PET) imaging. ${ }^{62,63}$ Grafting this bifunctional chelator did not affect the biorecognition of EGFR-targeted nanoparticles by FaDu cells, as shown in Fig. 6, where following NOTA conjugation to the corresponding batch uptake behaviour remains unchanged.

Moreover, NOTA-functionalisation of $\mathrm{SiO}_{2}-\mathrm{SdAb}$ has no influence on the formation of the biomolecular corona (Fig. 5). NOTA-conjugated nanoparticles were radiolabelled by incubation with $\left[{ }^{64} \mathrm{Cu}\right] \mathrm{CuCl}_{2}$ solution at room temperature for up to $1 \mathrm{~h}$. Within this time period, a radiochemical yield of $>98 \%$

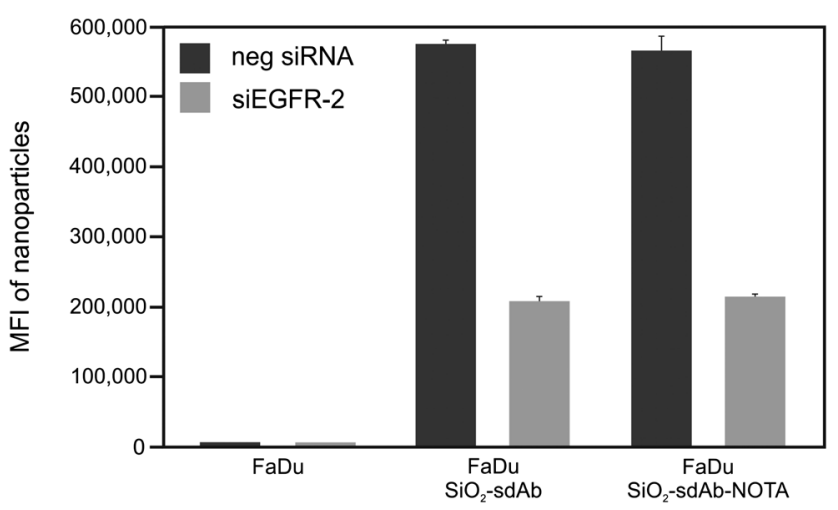

Fig. 6 Uptake of $\mathrm{SiO}_{2}-\mathrm{sdAb}$ and $\mathrm{SiO}_{2}-\mathrm{sdAb}-\mathrm{NOTA}$ by flow cytometry in FaDu cells. Median cell fluorescence intensities determined by flow cytometry of FaDu cells exposed to $10 \mu \mathrm{g} \mathrm{mL}^{-1} \mathrm{SiO}_{2}-\mathrm{sdAb}$ or $\mathrm{SiO}_{2}-$ sdAb-NOTA, respectively, showing that the uptake is not affected by nanoparticle modification with 1,4,7-triazacyclononane-triacetic acid (NOTA).
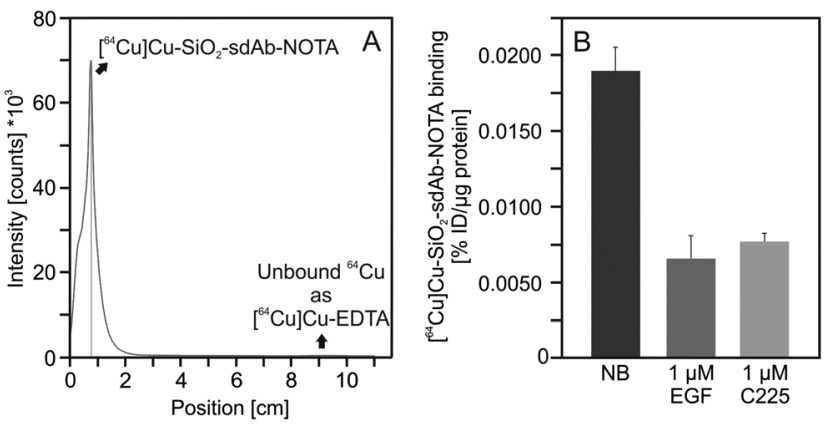

Fig. 7 Radiolabelling and cellular binding of $\mathrm{SiO}_{2}-\mathrm{sdAb}-\mathrm{NOTA}$. After modification with 1,4,7-triazacyclononane-triacetic acid (NOTA), sdAb-functionalized silica nanoparticles were labelled with ${ }^{64} \mathrm{Cu}$ until a radiochemical purity of $>98 \%$ was obtained as analysed by radio-TLC (A). A $1 \mu \mathrm{M}$ excess of human epidermal growth factor (EGF) or of the EGFR-inhibitory antibody Cetuximab (C225), respectively, blocks binding of radiolabelled sdAb-functionalized silica nanoparticles to EGFR-presenting FaDu cells. Binding data are expressed as \% of injected dose per $\mu \mathrm{g}$ protein (\%ID per $\mu \mathrm{g}$ protein). Each point represents the mean \pm SD of three samples.

(as analysed by radio-TLC) was obtained and longer incubation times did not improve the radiochemical yield (Fig. 7A).

In order to investigate the competition of free human EGF with radiolabelled $\mathrm{SiO}_{2}$-SdAb-NOTA for EGFR binding, we analysed nanoparticle binding to FaDu cells in the presence of an excess of this endogenous ligand (Fig. 7B). Upon incubation of FaDu cells with free human EGF, targeting of $\mathrm{SiO}_{2}-\mathrm{sdAb}-$ NOTA to EGFR is lost. Furthermore, the therapeutic antibody Cetuximab competes for the binding to EGFR, suggesting that sdAb-functionalized nanoparticles bind epitopes overlapping with or in close proximity to EGF and Cetuximab binding sites. To investigate EGF competition in more detail, we determined cellular binding of radiolabelled $\mathrm{SiO}_{2}$-sdAb-NOTA to FaDu in the presence of increasing EGF concentrations (Fig. 8).

No reduction of nanoparticle binding was observed up to 200 pM EGF, whereas higher concentrations of the endogenous EGFR ligand substantially decrease receptor-specific nanoparticle interaction. An EGF concentration of $500 \mathrm{nM}$ completely blocks the corresponding receptor and remaining nanoparticle binding occurs by EGFR non-specific nanoparticle-cell interaction. However, at physiological EGF serum concentrations ranging from $10 \mathrm{pM}$ to $190 \mathrm{pM},{ }^{64,65}$ no impairment of $\mathrm{SiO}_{2}$-sdAb-NOTA binding to their molecular target was observed. Concentration of EGF in the human serum used here was determined by either dilution of serum $\left(1280 \mathrm{pg} \mathrm{mL}^{-1}\right)$ or by serum spiking (1145 $\mathrm{pg} \mathrm{mL}^{-1}$ ). These values correspond to $\sim 180$ to $200 \mathrm{pM}$ and are in good agreement with EGF levels of other commercially available pooled serum samples (Fig. S3†).

Overall, the presented results clearly illustrate the strong influence of the corresponding biological context on the efficiency of receptor-specific nanoparticle targeting. Recently we have shown that targeting specificity of transferrin-conjugated nanoparticles is lost upon transfer to a complex biological environment. Furthermore, we found that proteins in the cell culture media restrain NP surface bound transferrin from interacting with its receptor. ${ }^{26}$ The results presented herein 


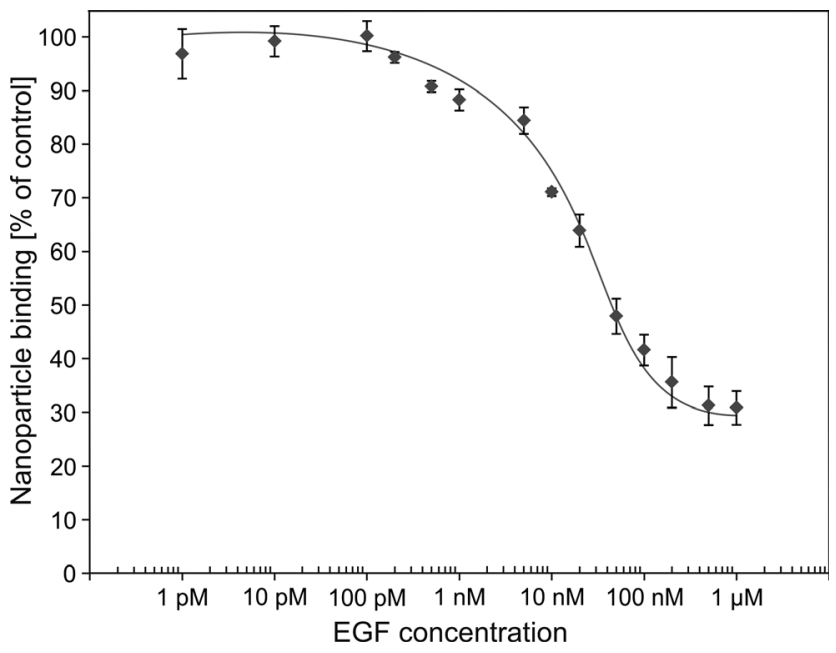

Fig. 8 Competition curves of human epidermal growth factor versus $\left[{ }^{64} \mathrm{Cu}\right] \mathrm{Cu}-\mathrm{SiO}_{2}-\mathrm{sdAb}-\mathrm{NOTA}$ using $\mathrm{FaDu}$ cells. Binding of radiolabelled sdAb-functionalized silica nanoparticles to EGFR-presenting FaDu cells was investigated in the presence of increasing concentrations of EGF. Percentage of bound activity was calculated in the way that the mean counts of a triplicate data point were related to the counts of data points without competitor. All counts were decay corrected. Each point represents the mean \pm SD of three samples.

confirm these findings, since in both cases we observed that the efficiency of receptor-specific nanoparticle targeting is affected by the biological context. However, for the sdAb-EGFR ligandreceptor pair we see that the specificity is reduced, but not obscured completely. These observations clearly illustrate, that results obtained in biologically irrelevant conditions (e.g. simple buffer systems, serum-free conditions) are not very meaningful. As a minimal prerequisite we suggest to carry out cellular binding and uptake studies in the biological fluids in which the particles will be applied. However, currently no prediction can be made as to if a certain ligand-nanoparticle conjugate maintains its specificity in complex biological context. This means that targeting ability has to be checked for every single ligand-receptor pair.

\section{Experimental}

\section{Nanoparticles synthesis}

Tetraethyl orthosilicate (TEOS; \#86578), (3-aminopropyl)trimethoxysilane (APTMS; \#281778), fluorescein isothiocyanate isomer I (FITC; \#F7250), rhodamine B isothiocyanate (RITC; \#283924), tris(2-carboxyethyl)phosphine hydrochloride (\#C4706) were all purchased from Sigma-Aldrich. Succinimidyl-([N-maleimidoproprionamido]-octylethyleneglycol)ester(SM(PEG) $\left.)_{8}\right)$ and $N$-succinimidyl- $S$-acetyl(thiotetraethylene glycol) $\quad\left(\mathrm{SAT}(\mathrm{PEG})_{4}\right)$ were purchased from Thermo Scientific. $S$-2-(4-Isothiocyanatobenzyl)-1,4,7-triazacyclononane-1,4,7-triacetic acid (SCN-Bn-NOTA; \#B-605) was purchased from Macrocyclics.

\section{Dye conjugate solution}

$N$-1-(3-Trimethoxysilylpropyl)- $N$-fluoresceyl thiourea (FITCAPTMS) or (RITC-APTMS) conjugate solutions were prepared by dissolving $4 \mathrm{mg}$ of reactive dye in $2 \mathrm{~mL}$ of anhydrous ethanol. Twenty $\mu \mathrm{L}$ of APTMS (about $11 \times$ molar excess) was then added immediately to this solution, with the mixture then shaken at room temperature in darkness for $4 \mathrm{~h}$. The reaction time course was initially monitored by ${ }^{1} \mathrm{H}$ NMR $\left(\mathrm{CD}_{3} \mathrm{OD}\right)$.

\section{Nanoparticle preparation}

To $25 \mathrm{~mL}$ of EtOH (99.9\%) was added $0.91 \mathrm{~g}$ of aq. ammonia (28.0-30.0\% $\mathrm{NH}_{3}$ basis) in a polypropylene container. To this mixture, under rapid stirring, was added $500 \mu \mathrm{L}$ of the prepared conjugate solution. The reaction was stirred for $15 \mathrm{~min}$, upon which TEOS $(940 \mu \mathrm{L})$ was added. The reaction was then stirred at $600 \mathrm{rpm}$ at $25^{\circ} \mathrm{C}$ for further $20 \mathrm{~h}$ in darkness. The resulting nanoparticle suspension was centrifuged down at $14000 \mathrm{rpm}$ for $20 \mathrm{~min}$, with the pellet then resuspended in fresh EtOH aided by bath sonication. This washing procedure was repeated twice more, followed by three water washes and a final resuspension in water at a total volume of $12 \mathrm{~mL}$.

\section{Surface amination}

The FITC-SiO ${ }_{2}$ particles were suspended in water at a concentration of $10 \mathrm{mg} \mathrm{mL}^{-1}$ and to this suspension APTES was added to a final concentration of 1 vol\%. The reaction which proceeded with gradual agglomeration visible, was shaken at $600 \mathrm{rpm}$ for $2 \mathrm{~h}$ at room temperature followed by incubation at $90{ }^{\circ} \mathrm{C}$ for $1 \mathrm{~h}$. The particles were cleaned by centrifugation and resuspension in water four times, giving a final clear suspension. The number of amines presented at the NP surface was measured by ninhydrin assay. Following centrifugal washing of NPs into pure ethanol $(\times 3)$ they were then incubated with ninhydrin reagent $\left(0.7 \mathrm{mg} \mathrm{mL}^{-1}\right)$ in absolute ethanol at $60{ }^{\circ} \mathrm{C}$ for 30 minutes and measured against APTES standard curves.

\section{Protein conjugation to pegylated nanoparticles}

To $0.12 \mu \mathrm{mol}$ of protein (per $10 \mathrm{mg}$ nanoparticles) dissolved at a concentration of $2 \mathrm{mg} \mathrm{mL} \mathrm{mL}^{-1}$ in PBS (pH 7.4) was added $\mathrm{SAT}(\mathrm{PEG})_{4}$ dissolved in dimethyl sulfoxide (DMSO) $(76 \mu \mathrm{L}$ of $\left.1 \mathrm{mg} \mathrm{mL}{ }^{-1}, 0.18 \mu \mathrm{mol}\right)$. After $30 \mathrm{~min}$ shaking slowly at room temperature, $100 \mu \mathrm{L}\left(\mathrm{mL}^{-1}\right.$ reaction) of deacetylation buffer composed of $0.5 \mathrm{M}$ hydroxylamine and $25 \mathrm{mM}$ ethylenediaminetetraacetic acid (EDTA) in PBS, pH 7.4 was added. The reaction was allowed to continue for $2 \mathrm{~h}$, followed by cleaning on a Sephadex G25 column with exchange into deoxygenated $20 \mathrm{mM}$ HEPES buffer ( $\mathrm{pH}$ 7.4). The collected protein fraction was then incubated for five minutes with tris(2-carboxyethyl)phosphine (TCEP) $(0.24 \mu \mathrm{mol})$ before mixing with PEG modified NPs.

\section{Nanoparticle pegylation}

The aminated particles were washed twice with $20 \mathrm{mM}$ HEPES buffer ( $\mathrm{pH}$ 7.4) by centrifugation, before resuspension in the same buffer at a concentration of $10 \mathrm{mg} \mathrm{mL}^{-1}$. They were added to an equal volume solution of freshly diluted $5 \mathrm{mg} \mathrm{mL}{ }^{-1} \mathrm{SM}$ $\mathrm{PEG}_{8}$-Mal, which corresponds to around $10 \times$ close packed monolayer in $20 \mathrm{mM}$ HEPES ( $\mathrm{pH} 7.4$ ), with mixing. The clear 
suspension reaction was shaken for $2 \mathrm{~h}$ followed by centrifugation at $14000 \mathrm{rpm}$ and two washes with $20 \mathrm{mM}$ HEPES buffer $(\mathrm{pH} 7.4)$ and then finally resuspended in deoxygenated $20 \mathrm{mM}$ HEPES buffer ( $\mathrm{pH} 7.4$ ) to a final concentration of $10 \mathrm{mg} \mathrm{mL}^{-1}$ nanoparticles. The work was timed so that the modified protein solution and modified particle dispersion would be ready simultaneously and were then combined in a ratio of $0.12 \mu \mathrm{mol}$ proteins per $10 \mathrm{mg}$ particles with a nanoparticle reaction concentration of $5 \mathrm{mg} \mathrm{mL}^{-1}$ and shaken gently together for $2 \mathrm{~h}$ at RT before incubating at $4{ }^{\circ} \mathrm{C}$ overnight. The solution was then cleaned of unreacted protein by centrifugation and resuspension three times in filtered $20 \mathrm{mM}$ HEPES ( $\mathrm{pH}$ 7.4). The number of bound proteins was measured by micro BCA assay against their corresponding preserved PEG control samples.

\section{Chelator conjugation to nanoparticles}

Five $\mathrm{mg}(8.9 \mu \mathrm{mol})$ of SCN-Bn-NOTA was dissolved in DMSO $(1000 \mu \mathrm{L})$. Seven $\mu \mathrm{L}(60 \mathrm{nmol})$ of this solution was then added to $0.5 \mathrm{~mL}$ of NP suspension (5 mg NP, $12.6 \mathrm{nmol} \mathrm{sdAb}$ ) giving a reaction ratio of approx. $5: 1$ (reactive macrocycle: sdAb), with immediate mixing by inversion. The dispersion was then slowly shaken for $30 \mathrm{~min}$ followed by washing by three cycles of centrifugation (12000 rpm for $15 \mathrm{~min}$ ) and resuspension in $20 \mathrm{mM}$ HEPES (pH 7.4).

\section{Differential centrifugal sedimentation (DCS) and dynamic light scattering (DLS)}

Nanoparticle dispersion was measured by DLS performed on a Malvern Nanosizer ZS. Particles were suspended at a concentration of $100 \mu \mathrm{g} \mathrm{mL}{ }^{-1}$ in the relevant buffer. Size measurements were averaged results from $3 \times 11$ runs. DCS experiments were performed with a CPS Disc Centrifuge DC24000 (CPS Instruments). Particles were injected at a concentration of $500 \mu \mathrm{g} \mathrm{mL}^{-1}$ into a $24-8 \%$ sucrose-suspension medium (water or PBS) gradient spinning at $20000 \mathrm{rpm}$.

\section{Radiolabelling and instant thin-layer chromatography}

The production of ${ }^{64} \mathrm{Cu}$ was performed at Cyclone® $18 / 9$ (Helmholtz-Zentrum Dresden-Rossendorf) in a ${ }^{64} \mathrm{Ni}(\mathrm{p}, \mathrm{n}){ }^{64} \mathrm{Cu}$ nuclear reaction with specific activities of $150-250 \mathrm{GBq} \mu \mathrm{mol}^{-1}$ $\mathrm{Cu}$ diluted in $\mathrm{HCl}(10 \mathrm{mM}) .{ }^{66}$ To $100 \mu \mathrm{g}$ of $\mathrm{SiO}_{2}-\mathrm{SdAb}-\mathrm{NOTA}$ nanoparticles in $100 \mu \mathrm{L} 10 \mathrm{mM}$ MES, pH 6.0, $1 \mathrm{MBq}\left[{ }^{64} \mathrm{Cu}\right] \mathrm{CuCl}_{2}$ was added and incubated at room temperature for $60 \mathrm{~min}$. A $5 \mu \mathrm{L}$ aliquot of the reaction was combined with 2 nmol EDTA, $\mathrm{pH} 7.0$ and the labelling process of the nanoparticles $\left(R_{\mathrm{f}}=0\right)$ was monitored by radio-TLC using ITLC-SA plates (Merck Millipore) in combination with a mobile phase of $0.9 \% \mathrm{NaCl}$ in $\mathrm{dH}_{2} \mathrm{O}$. As control, separate radio-TLC analysis of $\left[{ }^{64} \mathrm{Cu}\right] \mathrm{Cu}-$ EDTA $\left(R_{\mathrm{f}}=1\right)$ was performed in the same mobile phase. Evaluation of radio-TLC was carried out using a radioactivity thin layer analyser (Rita Star, Raytest).

\section{Heterologous expression and purification of sdAb}

Single-domain antibodies were expressed and purified as described recently. ${ }^{49}$

\section{Cell culture}

Tissue culture reagents were purchased from Biochrom AG and GIBCO Invitrogen Corporation/Life Technologies Life Sciences unless otherwise specified. The adherent human tumour cell lines A431 (ATCC® number: CRL-1555), FaDu (ATCC® number: HTB-43) and MDA-MB 435S (ATCC® number: HTB-129) were maintained as monolayer cultures in DMEM supplemented with $10 \%$ foetal calf serum (FCS), respectively, and incubated in a humidified atmosphere of $95 \%$ air $/ 5 \% \mathrm{CO}_{2}$ at $37{ }^{\circ} \mathrm{C}$. All cell lines were confirmed to be mycoplasma negative using the LookOut mycoplasma PCR detection kit (Sigma-Aldrich) and were tested monthly.

\section{Cell silencing and flow cytometry}

A total of 30000 cells were seeded in 24 well plates (Greiner), and incubated for $24 \mathrm{~h}$ before silencing of the gene coding for epidermal growth factor receptor (EGFR). Cells were then transfected with 15 pmol of Silencer Select siRNA siEGFR-1 (\#s563) or siEGFR-2 (\#s564) using Oligofectamine ${ }^{\mathrm{TM}}$ according to the manufacturer's instructions (Life Technologies). Neg1 silencer was used as a negative control. Cells were transfected with siRNAs in all experiments $48 \mathrm{~h}$ before exposure to nanoparticles or labelled EGF. After $48 \mathrm{~h}$ silencing, cells were washed for $10 \mathrm{~min}$ in serum-free DMEM. The medium was then replaced by the nanoparticle dispersions, freshly prepared by diluting the nanoparticle stock in serum-free DMEM, or medium supplemented with different concentration of FCS or human serum, for different times, depending on the experiment. Similar experiments were performed by exposing cells to $200 \mathrm{ng} \mathrm{mL}^{-1}$ Alexa Fluor ${ }^{\circledR}$ 488-labelled human EGF in serumfree DMEM. For flow cytometry, cells were washed once with DMEM supplement with 10\% FCS and twice with PBS and harvested with trypsin. Cell pellets were then fixed at room temperature with $4 \%$ formalin (Sigma-Aldrich) for $20 \mathrm{~min}$, and resuspended in PBS before cell-associated fluorescence (15 000 cells per sample) was measured using an Accuri C6 reader (BD Accuri Cytometers). The results are reported as the median of the distribution of cell fluorescence intensity, averaged over two to three independent replicates. Error bars represent the standard deviation between replicates. Each experiment was performed at least three times.

\section{Confocal microscopy}

For confocal microscopy, $10^{4}$ cells were seeded onto $35 \mathrm{~mm}$ plates with $15 \mathrm{~mm}$ diameter glass coverslips and grown for $24 \mathrm{~h}$ prior to silencing. After $48 \mathrm{~h}$ silencing, both silenced cells and non-silenced cells (controls) were exposed to fluorescently labelled EGF protein (Alexa Fluor ${ }^{\circledR}$ 488-conjugated, at a concentration of $200 \mathrm{ng} \mathrm{mL}{ }^{-1}$ for $2 \mathrm{~h}$ ) and to $\mathrm{SiO}_{2}-\mathrm{SdAb}$ nanoparticles at a concentration of $10 \mu \mathrm{g} \mathrm{mL}^{-1}$ for $30 \mathrm{~min}$ and for 6 h. For organelle and protein staining, samples were then washed three times with $1 \mathrm{~mL}$ PBS, fixed for $20 \mathrm{~min}$ with $1 \mathrm{~mL}$ of $4 \%$ formalin at room temperature. The cell-membrane was permeabilised using $1 \mathrm{~mL}$ of $0.1 \%$ saponin (Sigma Aldrich) solution for $5 \mathrm{~min}$ at room temperature and cell were then 
incubated for $30 \mathrm{~min}$ at room temperature with a blocking solution of $1 \%$ bovine serum albumin fraction $\mathrm{V}$ (Sigma Aldrich) in PBS-Tween to prevent antibody non-specific binding. Samples were then incubated for $1 \mathrm{~h}$ at room temperature with a primary antibody $1: 200$ rabbit polyclonal to LAMP-1 (Abcam) and with a primary antibody 1:200 mouse monoclonal antibody to EGFR (Abcam), washed three times with $1 \mathrm{~mL} \mathrm{PBS}$, and then incubated at room temperature for $1 \mathrm{~h}$ with 1 : 400 dilution of Alexa Fluor ${ }^{\circledR} 488$ goat anti-rabbit IgG and with 1 : 400 dilution of Alexa Fluor® 647 goat anti-mouse IgG as secondary antibodies (Molecular Probes, Life Technologies). Samples were washed three times with $1 \mathrm{~mL}$ PBS and incubated for $5 \mathrm{~min}$ with DAPI (Sigma Aldrich) before mounting with MOWIOL (Polysciences Inc.) on slides for imaging. The cells were observed using a Carl Zeiss LSM 510 Meta laser scanning confocal microscope with lasers at $364 \mathrm{~nm}$ and long pass filter LP $385 \mathrm{~nm}$ (DAPI), $488 \mathrm{~nm}$ and band pass filter 505$530 \mathrm{~nm}$ (fluorescently labelled EGF protein and LAMP-1 antibody), $543 \mathrm{~nm}$ and band pass filter 558-612 $\mathrm{nm}$ (nanoparticles) and $633 \mathrm{~nm}$ and band pass filter 644-719 nm filter (EGFR antibody).

\section{Serum characterisation}

Human serum (Biochrom AG) was tested for total protein content using a bicinchoninic acid (BCA) protein assay (Thermo Scientific). The amount of EGF present in human serum was quantified using a Human EGF ELISA Kit (Invitrogen). The ELISA assay was carried out according to manufacturer's specifications. The absorbance at $450 \mathrm{~nm}$ was read using a SpectraMAX 190 plate reader. Two approaches were used and compared in order to determine the concentration of EGF. The first method was carried out by serially diluting serum and examining the levels of EGF quantified for each of the diluted samples. The second approach involved spiking a sample of serum with known amounts of EGF and measuring the response observed in the assay.

\section{In vitro binding and uptake studies of radiolabelled $\mathrm{SiO}_{2}^{-}$ sdAb-NOTA}

A total of 50000 cells were seeded in 24 well plates (Greiner) and cultivated for $24 \mathrm{~h}$ before exposure to nanoparticles. After $24 \mathrm{~h}$, cells were washed for twice with warm PBS. The buffer was then replaced by the nanoparticle dispersions, freshly prepared by diluting the radiolabelled nanoparticle stock in serum-free DMEM, or medium supplemented with different concentration of FCS or human serum, for different times, depending on the experiment. Following treatment with radiolabelled nanoparticles for certain time periods, cells were washed twice with PBS in order to ensure removal of loosely attached nanoparticles from the cellular membrane. Finally, cell lysis was achieved by the addition of $1 \%$ SDS in $0.1 \mathrm{M} \mathrm{NaOH}$ and incubation for $30 \mathrm{~min}$ at room temperature with vigorous shaking. The radioactivity in the cell extracts was quantified using an automated gamma counter (PerkinElmer Life and Analytical Sciences). Total protein concentration in cell extracts was determined colorimetrically with the DC Protein Assay (Bio-Rad
Laboratories) according to the manufacture's microplate assay protocol using bovine serum albumin as protein standard.

\section{Competition assay}

A total of $15000 \mathrm{FaDu}$ cells were seeded in 48 well plates (Greiner) and cultivated for $24 \mathrm{~h}$ before exposure to nanoparticles. After $24 \mathrm{~h}$, cells were washed twice with ice-cold PBS and incubated on ice for $30 \mathrm{~min}$. Subsequently, different concentrations of human EGF ranging from $1 \mathrm{pM}$ up to $1 \mu \mathrm{M}$ as well as $10 \mu \mathrm{g} \mathrm{mL}{ }^{-1}$ radiolabelled $\mathrm{SiO}_{2}-\mathrm{SdAb}-\mathrm{NOTA}$ were added. After further incubation on ice for $2 \mathrm{~h}$, cells were washed twice with ice-cold PBS, lysed by addition of $1 \%$ SDS in $0.1 \mathrm{M} \mathrm{NaOH}$ and incubated for $30 \mathrm{~min}$ at room temperature with vigorous shaking. The radioactivity in the cell extracts was quantified using an automated gamma counter (PerkinElmer Life and Analytical Sciences).

\section{Isolation and characterisation of nanoparticle-protein complexes}

Biomolecular corona forming on silica nanoparticles was isolated as described recently with slight modifications. ${ }^{59}$ Briefly, samples containing $100 \mu \mathrm{g} \mathrm{mL} \mathrm{mL}^{-1}$ of $\mathrm{SiO}_{2}, \mathrm{SiO}_{2}-\mathrm{SdAb}$ or $\mathrm{SiO}_{2}-$ sdAb-NOTA, respectively, were incubated with $50 \mathrm{mg} \mathrm{mL}^{-1}$ of "off the clot" human serum (Biochrom AG) diluted with $\mathrm{d}_{2} \mathrm{O}$ for $1 \mathrm{~h}$ at $37{ }^{\circ} \mathrm{C}$ in protein LoBind vials (Eppendorf) with significantly reduced protein-to-surface binding. After incubation in serum, samples were centrifuged for $20 \mathrm{~min}$ at $10000 \times$ $g$ at $4{ }^{\circ} \mathrm{C}$ to pellet the nanoparticle-protein complexes and to remove the supernatant serum. The pellet was then washed three times with $1 \mathrm{~mL} \mathrm{dH_{2 }} \mathrm{O}$ and centrifuged again for $20 \mathrm{~min}$ at $10000 \times g$ at $4{ }^{\circ} \mathrm{C}$ to remove proteins with low affinity for the nanoparticle surface. Before the last centrifugation step, the nanoparticle dispersions were transferred into new vials in order to discard proteins bound to the inner surface of the vials. The nanoparticle-protein pellet was resuspended in Laemmli sample buffer (Bio-Rad Laboratories) immediately after the last centrifugation step and incubated for $5 \mathrm{~min}$ at $100{ }^{\circ} \mathrm{C}$ to denature the proteins. After cooling to room temperature, the samples were finally loaded on a $12 \%$ polyacrylamide gel and subjected to electrophoresis until the bromophenol blue dye of the sample buffer reached the end of the gel. On each gel, one lane was used to separate a molecular weight ladder standard, the PageRuler pre-stained protein ladder (Thermo Fisher Scientific). After electrophoresis, proteins were stained with PageBlue protein staining solution (Thermo Fisher Scientific) according to the manufacturer's instructions.

\section{Conclusions}

In conclusion, sufficient specific recognition of targeting ligands grafted to the surface of nanoparticles by their corresponding receptors depends on a variety of factors. These include the binding affinity of the ligated nanoparticle to its molecular target as well as the endogenous competitor concentration, and both factors influence the residence time for a ligand at its receptor binding site. The dissociation constant, 
which describes how tightly a particular ligand binds to its corresponding target, differs by one order of magnitude between the investigated peptide GE11 and the sdAb 7C12. It is not surprising, then, that the fraction of specific EGFR-mediated cellular uptake is substantially increased for sdAb-functionalized nanoparticles compared to their peptide-conjugated counterparts. However in this case, as for all nanoparticle-cell interaction studies there are a range of variables at play such as colloidal stability related to peptide pI, NP surface self-adsorption effects, etc. precluding direct comparison based on dissociation constants. In this study sdAb functionalized platforms were shown to function well in terms of biological recognition specific interactions. We observed a serum species type dependence in overall NP uptake where matching cell and serum protein for species resulted in the greatest diminution of overall nanoparticle uptake, suggesting the possibility of loss of specificity in situ. Our investigations using EGF competition studies suggest that it may not result mainly from endogenous EGF competition. Nevertheless, the sdAb-functionalized nanoparticles retain sufficient efficiency to remain credible candidates for further consideration.

We stress here the key overarching point. There is considerable potential for particles in situ to lose, or at least modulate, their specificity, compared to expectations in simple buffers. Even the differences between human and bovine serum, may be significant and clearly demonstrates the need to choose carefully appropriate experimental conditions and combinations in drawing conclusions from in vitro data. While we are not yet in a position to predict which ligands, and which ligation chemistries and nanoparticles lead to modulation of targeting efficiency, we believe that studies such as those presented here should be a basic prerequisite screen prior to more in depth consideration and in vivo study.

\section{Acknowledgements}

We thank Utta Herzog for excellent technical assistance. Financial support by the Helmholtz Virtual Institute NanoTracking (Agreement Number VH-VI-421) is gratefully acknowledged. This study is part of a research initiative "Technologie und Medizin - Multimodale Bildgebung zur Aufklärung des in vivo Verhaltens von polymeren Biomaterialien" of the Helmholtz-Portfoliothema. Financial support through Science Foundation Ireland and the Irish Research Council (IRC) are gratefully acknowledged. The work performed was supported by the IRC through an Enterprise Partnership Postdoctoral Fellowship with Intel (Ireland) (Ref no: EPSPD/2012/443) and the IRCSET EMPOWER Postdoctoral Fellowship Scheme. Experimental method development supported through the QualityNano research infrastructure is acknowledged.

\section{Notes and references}

1 K. Bourzac, Nature, 2012, 491, S58-S60.

2 M. Ferrari, Nat. Rev. Cancer, 2005, 5, 161-171.
3 B. Y. Kim, J. T. Rutka and W. C. Chan, N. Engl. J. Med., 2010, 363, 2434-2443.

4 A. H. Faraji and P. Wipf, Bioorg. Med. Chem., 2009, 17, 29502962.

5 J. A. Barreto, W. O'Malley, M. Kubeil, B. Graham, H. Stephan and L. Spiccia, Adv. Mater., 2011, 23, H18-H40.

6 K. Cho, X. Wang, S. Nie, Z. G. Chen and D. M. Shin, Clin. Cancer Res., 2008, 14, 1310-1316.

7 S. Hirsjarvi, C. Passirani and J. P. Benoit, Curr. Drug Discovery Technol., 2011, 8, 188-196.

8 N. T. Huynh, E. Roger, N. Lautram, J. P. Benoit and C. Passirani, Nanomedicine, 2010, 5, 1415-1433.

9 A. Mitra, A. Nan, B. R. Line and H. Ghandehari, Curr. Pharm. Des., 2006, 12, 4729-4749.

10 C. Minelli, S. B. Lowe and M. M. Stevens, Small, 2010, 6, 2336-2357.

11 Y. Matsumura and H. Maeda, Cancer Res., 1986, 46, 63876392.

12 W. Gao, J. M. Chan and O. C. Farokhzad, Mol. Pharm., 2010, 7, 1913-1920.

13 A. K. Iyer, G. Khaled, J. Fang and H. Maeda, Drug Discovery Today, 2006, 11, 812-818.

14 R. K. Jain and T. Stylianopoulos, Nat. Rev. Clin. Oncol., 2010, 7, 653-664.

15 E. S. Lee, Z. Gao and Y. H. Bae, J. Controlled Release, 2008, 132, 164-170.

16 H. Maeda, J. Controlled Release, 1992, 19, 315-324.

17 H. Maeda, Adv. Drug Delivery Rev., 2001, 46, 169-185.

18 S. P. Egusquiaguirre, M. Igartua, R. M. Hernandez and J. L. Pedraz, Clin. Transl. Oncol., 2012, 14, 83-93.

19 N. Kamaly, Z. Xiao, P. M. Valencia, A. F. Radovic-Moreno and O. C. Farokhzad, Chem. Soc. Rev., 2012, 41, 2971-3010.

20 M. K. Yu, J. Park and S. Jon, Theranostics, 2012, 2, 3-44.

21 Y. H. Bae and K. Park, J. Controlled Release, 2011, 153, 198205.

22 H. S. Choi and J. V. Frangioni, Mol. Imaging, 2010, 9, 291310.

23 T. Lammers, F. Kiessling, W. E. Hennink and G. Storm, J. Controlled Release, 2012, 161, 175-187.

24 E. Mahon, A. Salvati, F. Baldelli Bombelli, I. Lynch and K. A. Dawson, J. Controlled Release, 2012, 161, 164-174.

25 V. Mirshafiee, M. Mahmoudi, K. Lou, J. Cheng and M. L. Kraft, Chem. Commun., 2013, 49, 2557-2559.

26 A. Salvati, A. S. Pitek, M. P. Monopoli, K. Prapainop, F. B. Bombelli, D. R. Hristov, P. M. Kelly, C. Aberg, E. Mahon and K. A. Dawson, Nat. Nanotechnol., 2013, 8, 137-143.

27 M. Mahmoudi, I. Lynch, M. R. Ejtehadi, M. P. Monopoli, F. B. Bombelli and S. Laurent, Chem. Rev., 2011, 111, 56105637.

28 M. P. Monopoli, C. Aberg, A. Salvati and K. A. Dawson, Nat. Nanotechnol., 2012, 7, 779-786.

29 A. Lesniak, F. Fenaroli, M. P. Monopoli, C. Aberg, K. A. Dawson and A. Salvati, ACS Nano, 2012, 6, 5845-5857.

30 A. Lesniak, A. Salvati, M. J. Santos-Martinez, M. Radomski, K. A. Dawson and C. Aberg, J. Am. Chem. Soc., 2013, 135, 1438-1444. 
31 S. R. Hubbard and W. T. Miller, Curr. Opin. Cell Biol., 2007, 19, 117-123.

32 J. Schlessinger, Cell, 2000, 103, 211-225.

33 A. Gschwind, O. M. Fischer and A. Ullrich, Nat. Rev. Cancer, 2004, 4, 361-370.

34 T. Holbro, G. Civenni and N. E. Hynes, Exp. Cell Res., 2003, 284, 99-110.

35 N. E. Hynes and G. MacDonald, Curr. Opin. Cell Biol., 2009, 21, 177-184.

36 M. Baumann and M. Krause, Radiother. Oncol., 2004, 72, 257-266.

37 M. Baumann, M. Krause, E. Dikomey, K. Dittmann, W. Dorr, U. Kasten-Pisula and H. P. Rodemann, Radiother. Oncol., 2007, 83, 238-248.

38 M. Krause, K. Gurtner, Y. Deuse and M. Baumann, Int. J. Radiat. Biol., 2009, 85, 943-954.

39 D. Zips, M. Krause, A. Yaromina, A. Dorfler, W. Eicheler, C. Schutze, K. Gurtner and M. Baumann, J. Pharm. Pharmacol., 2008, 60, 1019-1028.

40 A. Elbakri, P. N. Nelson and R. O. Abu Odeh, Hum. Immunol., 2010, 71, 1243-1250.

41 C. Van de Wiele, H. Revets and N. Mertens, Q. J. Nucl. Med. Mol. Imag., 2004, 48, 317-325.

42 L. O. Gainkam, L. Huang, V. Caveliers, M. Keyaerts, S. Hernot, I. Vaneycken, C. Vanhove, H. Revets, P. De Baetselier and T. Lahoutte, J. Nucl. Med., 2008, 49, 788-795.

43 L. O. Gainkam, M. Keyaerts, V. Caveliers, N. Devoogdt, C. Vanhove, L. Van Grunsven, S. Muyldermans and T. Lahoutte, Mol. Imag. Biol., 2011, 13, 940-948.

44 Z. Li, R. Zhao, X. Wu, Y. Sun, M. Yao, J. Li, Y. Xu and J. Gu, FASEB J., 2005, 19, 1978-1985.

45 S. Song, D. Liu, J. Peng, Y. Sun, Z. Li, J. R. Gu and Y. Xu, Int. J. Pharm., 2008, 363, 155-161.

46 F. M. Mickler, L. Mockl, N. Ruthardt, M. Ogris, E. Wagner and C. Brauchle, Nano Lett., 2012, 12, 3417-3423.

47 B. G. Ongarora, K. R. Fontenot, X. Hu, I. Sehgal, S. D. Satyanarayana-Jois and M. G. Vicente, J. Med. Chem., 2012, 55, 3725-3738.

48 S. Song, D. Liu, J. Peng, H. Deng, Y. Guo, L. X. Xu, A. D. Miller and Y. Xu, FASEB J., 2009, 23, 1396-1404.
49 K. Zarschler, S. Witecy, F. Kapplusch, C. Foerster and H. Stephan, Microb. Cell Fact., 2013, $12,97$.

50 S. R. Rangan, Cancer, 1972, 29, 117-121.

51 I. King and A. C. Sartorelli, Cancer Res., 1989, 49, 5677-5681.

52 J. Y. Song, S. W. Lee, J. P. Hong, S. E. Chang, H. Choe and J. Choi, Cancer Lett., 2009, 283, 135-142.

53 R. Cailleau, M. Olive and Q. V. Cruciger, In Vitro, 1978, 14, 911-915.

54 D. J. Giard, S. A. Aaronson, G. J. Todaro, P. Arnstein, J. H. Kersey, H. Dosik and W. P. Parks, J. Natl. Cancer Inst., 1973, 51, 1417-1423.

55 Z. Novy, P. Barta, J. Mandikova, M. Laznicek and F. Trejtnar, Nucl. Med. Biol., 2012, 39, 893-896.

56 M. Lundqvist, J. Stigler, T. Cedervall, T. Berggard, M. B. Flanagan, I. Lynch, G. Elia and K. Dawson, ACS Nano, 2011, 5, 7503-7509.

57 D. Walczyk, F. B. Bombelli, M. P. Monopoli, I. Lynch and K. A. Dawson, J. Am. Chem. Soc., 2010, 132, 5761-5768.

58 A. S. Pitek, D. O'Connell, E. Mahon, M. P. Monopoli, F. Baldelli Bombelli and K. A. Dawson, PLoS One, 2012, 7, e40685.

59 K. Pombo-García, K. Zarschler, J. A. Barreto, J. Hesse, L. Spiccia, B. Graham and H. Stephan, RSC Adv., 2013, 3, 22443.

60 A. T. Baron, J. M. Lafky, D. C. Connolly, J. Peoples, D. J. O'Kane, V. J. Suman, C. H. Boardman, K. C. Podratz and N. J. Maihle, J. Immunol. Methods, 1998, 219, 23-43.

61 J. M. Lafky, J. A. Wilken, A. T. Baron and N. J. Maihle, Biochim. Biophys. Acta, 2008, 1785, 232-265.

62 T. J. Wadas, E. H. Wong, G. R. Weisman and C. J. Anderson, Chem. Rev., 2010, 110, 2858-2902.

63 V. Maheshwari, J. L. J. Dearling, S. T. Treves and A. B. Packard, Inorg. Chim. Acta, 2012, 393, 318-323.

64 J. Brzezinski and A. Lewinski, Eur. J. Endocrinol., 1998, 138, 388-393.

65 A. Pietrzak, R. Miturski, D. Krasowska, K. Postawski and B. Lecewicz-Torun, J. Eur. Acad. Dermatol. Venereol., 1999, 12, 1-5.

66 S. Thieme, M. Walther, H. J. Pietzsch, J. Henniger, S. Preusche, P. Mading and J. Steinbach, Appl. Radiat. Isot., 2012, 70, 602-608. 